educational institutions was primarily concerned with puro science. Owing to the initiative of Mr. W. E. Collinge of the University of Birmingham and others, however, the Society of Applied Biologists (as it is now termed) came into being. And as 1938 marked the publication of the twenty-fifth volume of its journal (Annals of Applied Biology), Prof. W. Brierley, joint editor since 1921, has written an interesting account of the development of the Association (Ann. App. Biol., 26, 178; 1939), correlating it with more general trends of development in the country over the same period of years. From the outset the Society has welcomed all investigators in economic biology, whether agricultural, horticultural, medical or commercial, and since its inception has steadily widened its interests. The journal, too, has increased in scientific value, developing from a volume of 359 pages in 1922 to one of 891 pages in 1938. The inclusion of photographs of the presidents of the Association from 1904 up to the present time adds much to the interest of the retrospect.

\section{Agricultural Research Institutes}

THE reports on the work of the agricultural researeh institutes in the United Kingdom carried out during the year ending September 1936 have now been published (London: H.M. Stationery Office. 5s.). The volume also includes reports of a number of other investigations, particularly into animal diseases, set afoot by the Agricultural Research Council, and accounts of the research activities of the agricultural advisory officers. Those who require fuller informa. tion on any subject are invited to consult the original papers, a list of which is attached to each report, or to inquire of the director of the institution concerned. Farmers and others in need of advice on agricultural or horticultural matters are reminded that by applying to the agricultural organizer for their county, they can draw direct benefit from these research and advisory services. It is perhaps unfortunate that so much delay occurs before these reports are published, as thereby some of their value is inevitably lost.

\section{"Know Your School" Movement in the United States}

To the various agencies which foster local interest in the public schools of the United States, such as the official popular magazine School Life and parents' associations, a notable addition has recently been made. At the request of the American Association of University Women, the Office of Education pre. pared a series of study outlines of certain aspects of the public school system for the use of the Associa. tion's branches. These proved so widely acceptable that they are being reprinted as ten-page leaflets. Those already issued are: "Know your Board of Education" (Local Education Authority), "Know your Superintendent", "Know your School Principal" and "Know your Teacher". They deal simply and clearly with such questions as "What are the duties of the principal ?", "What should be his qualifications ?", "Relationship to the local education authority, to the superintendent, to supervisors, to teachers, to the school janitor, to the community". They are well adapted for guiding discussion by study circles and contain suggestions for investigation and dis. cussion. In an article by the president of the University of Chicago which appeared in The Times United States Supplement of June 8, reference is made to "thedeep and abiding faith of the people in education", and it concludes-" "we shall yet make good our boast. that we are giving the world a demonstration of education by and for democracy". The leaflets should serve as an acid test of this faith, and eventually tend to strengthen it.

\section{Manufacture of Rare Gases}

IN an article by H. C. A. Holleman on the manufacture of rare gases (Philips Tech. Rev., Nay), a method is described by which rare gases, as well as oxygen and nitrogen are obtained from the air at the Philips' factories at Eindhoven in Holland. During the Great War, when it became more and more difficult to import the argon necessary for filling the incandescent lamps made in the factory, they were forced to manufacture the gas itself and a gas liquofaction plant was installed. This plant continued to grow steadily after the War, as it was found to supply many needs. So many different gases, all of which can be obtained from liquid air, are used in the Philips' factories that it was very important to have the whole manufacture under one control. Besides argon, which is used for filling electric lamps, the rare gases helium and neon are also used in gas discharge tubes. For glass blowing and in the machine shops large quantities of oxygen are used in order to reach higher combustion temperatures than it is possible to reach with air. Liquid oxygen and nitrogen are both used on a large scale for cooling purposes and as aids in obtaining a high vacuum.

As a protective gas in the working of metal parts for electric lamps and radio valves, much use is made of a mixture of nitrogen and hydrogen. Nitrogen is also used during the manufacture of electric lamps as a washing gas, while it is also used to fill special kinds of lamps. A modern installation for the separation of air by the Linde method is described. Since krypton and xenon have relatively high boiling points, they collect in the liquid container below the main column, which contains oxygen for the most part. Methane occurs in variable amounts in the air and has about the samo boiling point as krypton, so that it is collected with the krypton in the liquid oxygen. This leads to difficulties in practice since liquid oxygen together with a combustible substance like methane can easily form an explosive mixture and lead to accidents. Hence the strictest precautions have to be taken in the preparation of krypton and xenon.

\section{Earthquakes registered at De Bilt during 1936}

The "Seismische Registrierungen in De Bilt", 24 ; 1936, published in November 1938 and written by Dr. G. Van Dijk with a foreword by Dr. H. G. Cannegieter, contains a description of the instruments in uso at the station with the constants necessary for the interpretation of the seismograms obtained, a list of the abbroviations used, acknowledgments, a short 
paragraph on microseisms together with a table, followed by fifty-three pages in small clear type of the earthqualies recorded. This record contains details of 443 earthquakes, giving in each caso the date, phase and time of recording, the period of the phase, direction of initial impulso and remarks. Tho remarks consist chiefly of amplitudes, epicentre, and readings obtained by other observers who have communicated with De Bilt. A very sound practico has been not to give the recorded time of every prominent pulso but to limit the identifications to $P$, $P P, P P P, S, S S, S S S, L$, and $M$ phases, so presenting very valuable data for seismological research in many directions.

\section{Diploma in Fuel and Refractory Materials at Leeds}

For many years past the University of Leeds has provided courses for post-graduate students leading to special diplomas both in gas engineering and in fuel and metallurgy. A one-year course leading to a post-graduate diploma in fuel and refractory materials has now been arranged, in order to meet the growing demand for men with special training in refractory materials. Commencing in October next, the new course will be given in the Department of Coal Gas and Fuel Industries, and will bo additional to the normal instruction in the subject received by all students reading for degrees in gas engineering and in fuel and metallurgy. An approved degree in science or technology is required as a preliminary qualifica. tion; and the subsequent specialized training in fuel and refractory materials is intended as preparation for entry into either the 'manufacturer' or 'user' sides of the refractories or allied industries. Particulars of these courses may be obtained from the Registrar of the University.

\section{Announcements}

The following awards of the Royal College of Physicians have recently been made: the Moxon Gold Medal to Sir Arthur Hurst, senior physician to Guy's Hospital, for his researches and observations in clinical medicine; the Baly Gold Medal to Prof. C. H. Best, professor of physiology in the University of Toronto, for his physiological researches; the Weber-Parkes Medal and Prize to Sir Pendrill Varrier-Jones, founder and medical director of the Papworth Village Settlement, for his work on tuberculosis at the Settlement.

Tre Council of the City and Guilds of London Institute has conferred the distinction of fellow of the Institute upon the following : Mr. L. B. Atkinson, Mr. C. R. Fairey, Mr. E. Fawssett, Dr. L. F. Goodwin, Sir Follett Holt, Sir Gilbert T. Morgan, Mr. F. Handley Page, Sir Leonard Pearce.

A TEAK memorial seat to the late Sir William Perkin, the chemist, is to be unveiled and dedicated to the public at Sudbury, Middlesex, on August 12. The memorial will be outside a recreation ground, and opposite the site where Sir William's house and laboratory stood. The cost of the memorial has been met by public subseription.
Dr. Givenvron MI. Griffitus has been appointed to the Kathleen Schlesinger research fellowship for the year 1939-40. The fellowship is provided from a fund established by the late Mr. Fugen M. Schlesinger and Mrs. Schlesinger in memory of their daughter, and is given for investigations of cysts of the brain or allied conditions. It is ordinarily tenable at the National Hospital for Diseases of the Nervous System, Queen Square, London.

Prof. Theodor VAhlen, president of the Prussian Academy of Sciences, has been awarded the Goethe Medal for Art and Science by the German Chancellor.

THE Medical Research Council has appointed Dr. Donald Hunter, physician to the London Hospital, and Mr. Harold E. Clay, national secretary of tho Passenger Services Group, Transport and General IVorkers' Union, to bo members of the Industrial Health Research Board, in succession to Prof. J. A. Nixon and Mr. R. Coppock.

Mr. E. J. LudLow of Brylls, Waltham St. Lawrence, Berks, has been awarded the Founders Company fellowship to commence in September next. Mr. Ludlow will be the first person to hold this fellowship, which has been recently created. The normal value of the fellowship is $£ 250$ a year and will be renewable for a second year and in special cases for a third year.

Mr. PaUl Vellacotr, headmaster of Harrow, has been elected master of Peterhouse, Cambridge, in succession to the late Prof. H. W. V. Temperley.

ThE fourth International Congress for Racial Hygiene will be held in Vienna on August 26-28 under the presidency of Prof. E. Rudin. The fee is 10 marks. Further information can be had from the Office of the Congress, Einemstrasse 11, Berlin, WV.62.

IN NATURE of March 25, p. 515, it was stated that the University of Peiping has been reopened under the direction of Prof. Hisomu Nagat, formerly of the University of Formosa. Monlin Chiang, writing as chancellor of the National University of Peking, states that the National University is now in Kunming, Yunnan, as part of the National Southwestern Associated University. He says that, following the fall of the city on July 29, 1937, all the national universities in Peiping moved with their faculties and staffs and almost 90 per cent of their students, leaving behind them practically all their books and apparatus, to the interior and combined into several groups under new names, of which the National Southwestern Associated University is one. As the evacuation took place during the summer vacation, these universities were able to reopen in their new homes more or less according to their original academic calendars, with what little equipment they had secured in the short interval.

Erratua.-In Nature of July 22, p. 150, the dates for the Congress of the International Union against Tuberculosis were incorrectly given as August 11-September 20. They should read September 16-20. 